Annals of Warsaw University of Life Sciences - SGGW

Land Reclamation No 43 (2), 2011: 101-111

(Ann. Warsaw Univ. of Life Sci. - SGGW, Land Reclam. 43 (2), 2011)

\title{
Slope erosion control with the use of fly-ash and sewage sludge
}

\author{
EUGENIUSZ KODA, PIOTR OSIŃSKI \\ Department of Geotechnical Engineering, Warsaw University of Life Sciences - SGGW
}

\begin{abstract}
Slope erosion control with the use of fly-ash and sewage sludge. The paper presents alternative methods of the earth slopes reinforcement. The techniques proposed utilise recycled materials such as fly-ash and sewage sludge. It is described how implementation of fly-ash made capping materials and hydroseeding method (with the use of the sewage sludge) can effectively control high earth slopes erosion, based on the example of embankment type landfill where remedial works were proceeded. Moreover, it is assessed how the influence of the vegetation cover on engineered landfills, can significantly increase the safety factor of slopes.
\end{abstract}

Key words: slope stability, reinforcement, vegetation cover, recycled materials, landfill.

\section{INTRODUCTION}

The most significant element of the embankment type landfill reclamation process is the reinforcement and biological stabilisation of slopes, which are very sensitive to several destabilisation processes like i.e surface erosion. The landfill stability improvement activities are divided into phase 1 - technical reclamation (implementation of civil engineering techniques), and phase 2 - biological restoration (establishment of the vegetation cover). For both of them it is highly recommended to use such recyclable materials as sewage sludge and fly ash as a landfill reinforcement filling (CEN/BT 2009).
In 2010, in Poland the production of flay-ashes from the coal combustion was $18.5 \mathrm{mln}$ tones. The amount of slag and ashes disposed on Polish landfills and usable for the road embankment construction and land reclamation is $261.8 \mathrm{mln}$ tons. Furthermore, the annual production of sewage sludge in Poland is also significant -500000 tones, and could be successfully utilised in landfill reclamation process, as a rich in nutrients fertiliser.

The combination of carefully selected types of fly-ash, sewage sludge, soil and vegetation cover can be excellent alternative for the heavy engineering activities for the landfill slopes reinforcement. The great example of the successful application of components mention above is capping system and hydroseeding method, which is described as a protection of the anthropogenic formations (landfills) against the influence of the water and wind erosion (Koda and Głażewski 2006).

\section{UTILISATION OF FLY-ASH}

The flay-ash is basically a by product of the coal combustion process in power plants. The mineral and chemical composition is determined by mineral elements present in coal. These minerals are: iron oxides, carbonates and clayey minerals. The chemical reactions proceeding during 
the coal combustion process produce mineral phases stated in Table 1.

TABLE 1. Mineral phases of the fly-ash

\begin{tabular}{|l|c|}
\hline Mineral phases & \% content of total mass \\
\hline Glass & $60-83$ \\
\hline Millite & $4-25$ \\
\hline Quartz & $4-18$ \\
\hline Hematite & $0.5-2$ \\
\hline Magnetite & $1-7$ \\
\hline Coke & $0.5-5$ \\
\hline
\end{tabular}

The properties of the flay-ash mainly depend on shape and size distribution of its particles. The bulk density of ashes contains in the range of $2000-2500 \mathrm{~kg} /$ $/ \mathrm{m}^{3}$. The reason for this is some of the particles are filled with gas. The range of the fly-ash utilisation is very wide. It can be applied as an additive for the cement or concrete production, and especially nowadays, as a filling material for the earth structures, and as a capping system or barriers for landfills reclamation procedures. The usability of ashes for the geotechnical purpose is determined by several physical and mechanical properties such as: capacity index in saturated conditions, grain-size distribution, maximum dry bulk density, swelling, internal friction angle, and passive capillarity. In order to prepare fly-ashes to be suitable for the geotechnical use, there are several mechanical and chemical treatment methods to obtain required size of particles or to eliminate danger contaminants from the ash. While utilising the fly ash the great attention has to be paid to issues like:

- dusting,

- water contamination,

- leaching,

- heavy metals content,
- radioactivity,

- volatile matter emission.

One of the elements of the landfill reclamation process is the construction of capping system. It is a landfill surface cover protecting against the rainfall infiltration (limitation of leachate penetration). It provides good establishment conditions for the vegetation cover, and significantly enhances landfill slopes stability. Because of its appropriate geotechnical properties like impermeability and good compaction conditions, flay-ashes mixed with cohesive soil are a great material for the capping system.

Recently it was recommended to use geomembrane instead of mineral barriers to insulate the surface of the landfill, however there are lots of disadvantages like decreasing slope stability or slowing down the bio-chemical decomposition of waste. Applying mineral capping systems

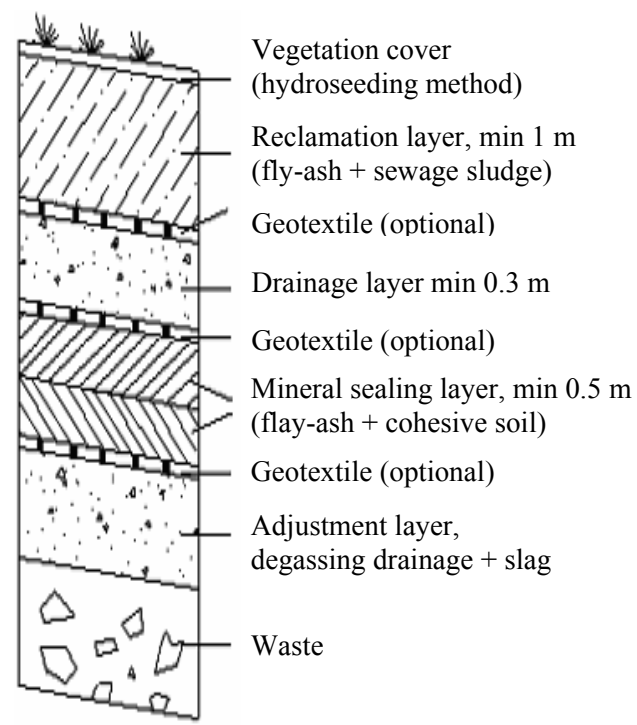

FIGURE 1. Fly-ash and sewage sludge made capping system for the surface erosion control, enhancing the landfill slopes stability 


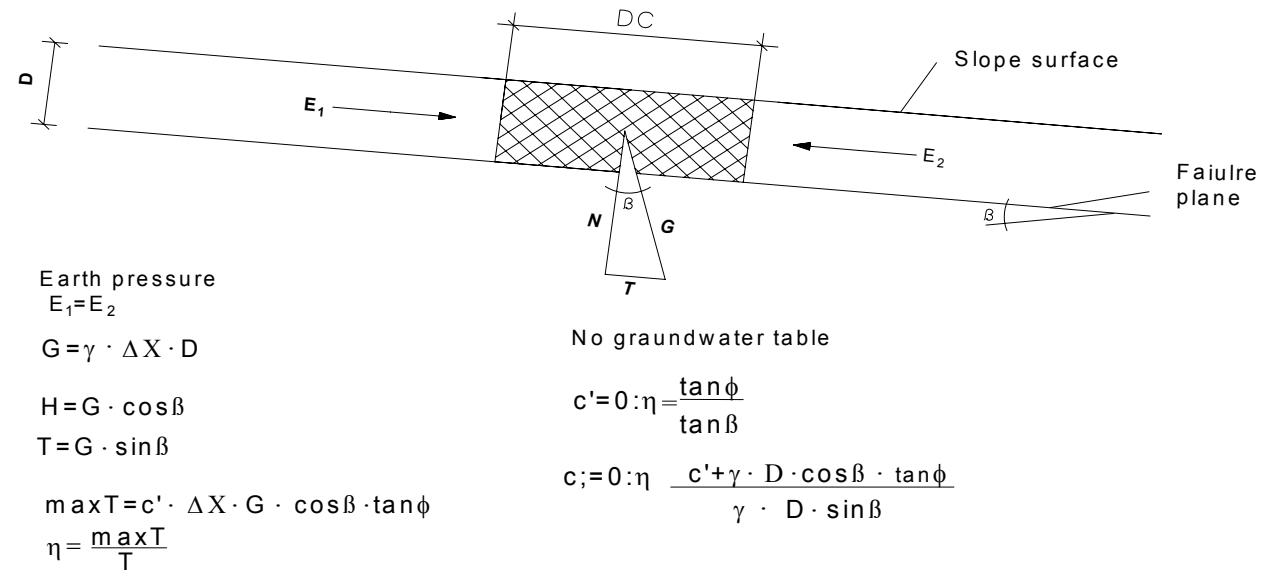

FIGURE 2. Determination of shear resistant on the contact plane, between capping system layers

(made of ashes), in many cases resulted in enhanced fermentation processes (Koda 1999). The Figure 1 presents suggested capping system solution, where fly-ash plays significant role in reinforcing landfill slopes.

The only, time consuming, difficulty in application of presented system is determination of the shear resistance on the contact plane between layers involved (Fig. 2). The huge advantage of using flay-ash as a slope stabilisation material is its positive influence on soil-creating mechanisms. This material consists of macro and micro minerals enhancing topsoil properties, which have great impact on vegetation cover establishment (Coppin and Richards 1990). Because of the nutrition richness it can be treated as an erosion resistant mineral fertiliser. After mixing it with sewage sludge and compost it becomes available for plants. Appropriate capping system construction and correct vegetation establishment provides great conditions of the landfill slopes cover.

\section{SEWAGE SLUDGE AND FLY ASH AS A CARRIER ELEMENT IN HYDROSEEDING}

The alternative methods of remedial works for the landfill slope stability improvement can be also a combination of sewage sludge (fly-ash optional) utilization with mulching, hydroseeding or injection techniques.

For the preparation of the mixture to be applied the sewage sludge with organic matter content higher than $50 \%$ can be used. The hydroseeding method presented in the paper is the technique prepared by the Road and Bridge Research Institute. The idea of the method is basically to spray steep landfill slopes with the suspension consisting of:

- $60 \mathrm{~m}^{3} / \mathrm{ha}$ of sewage sludge with the content of 3 to $12 \%$ of dry mass,

- $300 \mathrm{~kg} / \mathrm{ha}$ mixture of grass seeds (appropriate for the existing habitat),

- $200 \mathrm{~kg} / \mathrm{ha}$ of clean nitrogen in the mixture of natural fertilizers with the ratio $\mathrm{N}: \mathrm{P}: \mathrm{K} 1: 0.8: 1.2$. 
The composition of hydroseeding suspension, with the suggested amount of elements is presented in Table 2.

TABLE 2. The suggested composition of the hydroseeding suspension

\begin{tabular}{|l|c|}
\hline Ferment sewage sludge & $\begin{array}{c}12-301 \\
(4 \div 10 \% \text { of dry mass })\end{array}$ \\
\hline Mixture of grass seeds & $0.018-0.30 \mathrm{~kg}$ \\
\hline Bedding & $0.06-0.10 \mathrm{~kg}$ \\
\hline Fly-ash & $0.08-0.14 \mathrm{~kg}$ \\
\hline Mineral fertiliser & $0.02-0.05 \mathrm{~kg}$ \\
\hline
\end{tabular}

The mineral elements of the sewage sludge are developing slowly and are not exposed to the erosion processes. This kind of material is danger when disposed but when treated by vegetation and additives it is safely absorbed utilized by plants. Additionally it has to be mentioned that sewage sludge supply is free of charge. The mixture is applied by hydraulic seeders supplied with high pressure pumps, which enables spraying on different soil/material types. The advantage of using sewage sludge is that seeds are protected from the erosion and excessive drying. The viscosity of the sludge and its mixing ability with other components, assure even and smooth protection cover, and moreover, high adhesion to the sprayed surface. All these properties allow exceeding the hydroseeding to be applied in almost full vegetation period. Furthermore, the amount of seeds used decreases 30\% (Glazewski and Kalotka 1999). The development of described method allows utilisation of difficult to treat drained and undrained sludge instead of expensive erosion control formulation and fertilisers. Another advantage of using the sewage sludge is the nutrition content, essential for the vegetation cover establishment. Especially the undrained sludge is rich in microelement, nitrogen, phosphorus, potassium and organic matter. The content of elements mentioned is as follows: $\mathrm{N}-2.2 \%$ in total, $\mathrm{P}-0.7 \%, \mathrm{~K}-0.4 \%$ of dry mass, $\mathrm{OM}$ - in the range of $36-80 \%$ (mean $60 \%$ ) of dry mass. The undrained sludge also contains heavy metals like lead, chromium, cadmium. Some of them are highly valuable for plants (Koda and Pachuta 2004), however cannot exceed normative values of dry mass: $\mathrm{Pb}-2500$ $\mathrm{mg} / \mathrm{kg}, \mathrm{Cd}-50 \mathrm{mg} / \mathrm{kg}, \mathrm{Hg}-25 \mathrm{mg} / \mathrm{kg}$, $\mathrm{Ni}-300 \mathrm{mg} / \mathrm{kg}, \mathrm{Cr}-1500 \mathrm{mg} / \mathrm{kg}$.

\section{UTILISATION OF FLY ASH AND SEWAGE SLUDGE IN PRACTICE}

This system was successfully applied on the phosphogypsum waste dump in Gdansk (Phosphorus Fertilizers Factory) and on Radiowo landfill in Warsaw. The result obtained is presented below Figures 4 and 5.

To sum up, main advantages of using suspension of the sewage sludge in hydroseeding method as the effective technique for the landfill slope stability improvement are:

- the high level of works mechanisation,

- the possibility of obtaining the sod formation (turf) of good quality on the high inclination slope,

- utilisation of wastes which are troublesome for the communal and environmental treatment plants,

- reclamation of the sanitary landfills.

The overall scheme of techniques described above is presented in details in Figure 6. 


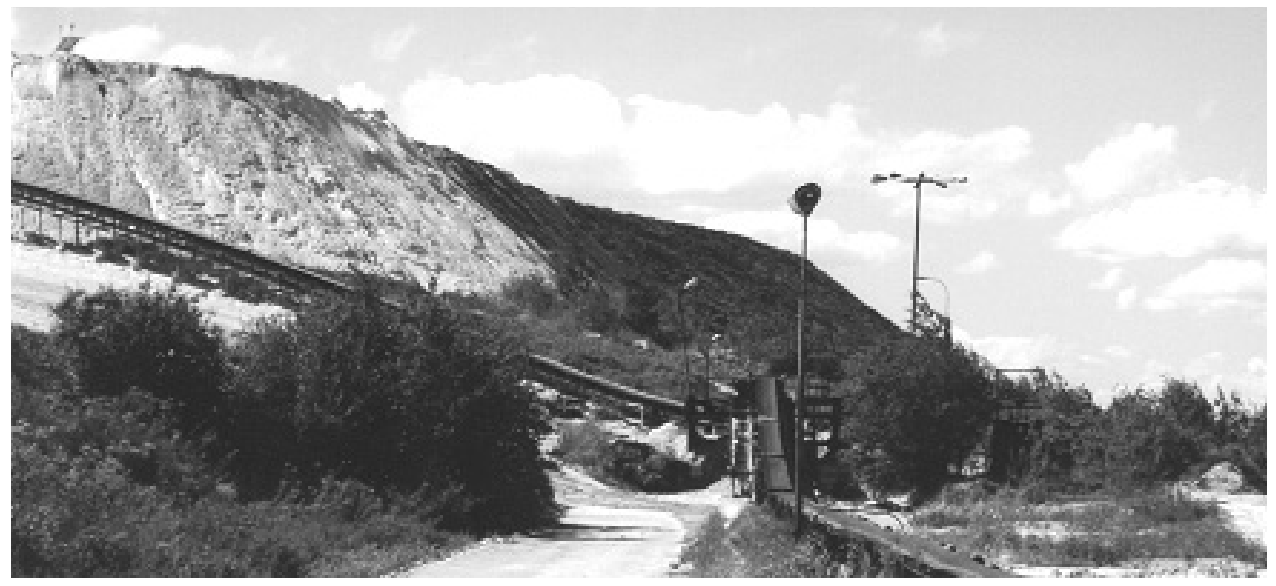

FIGURE 4. Hydroseeding method applied on the phosphogypsum waste dump in Gdańsk Phosphorus Fertilizers Factory - North slope

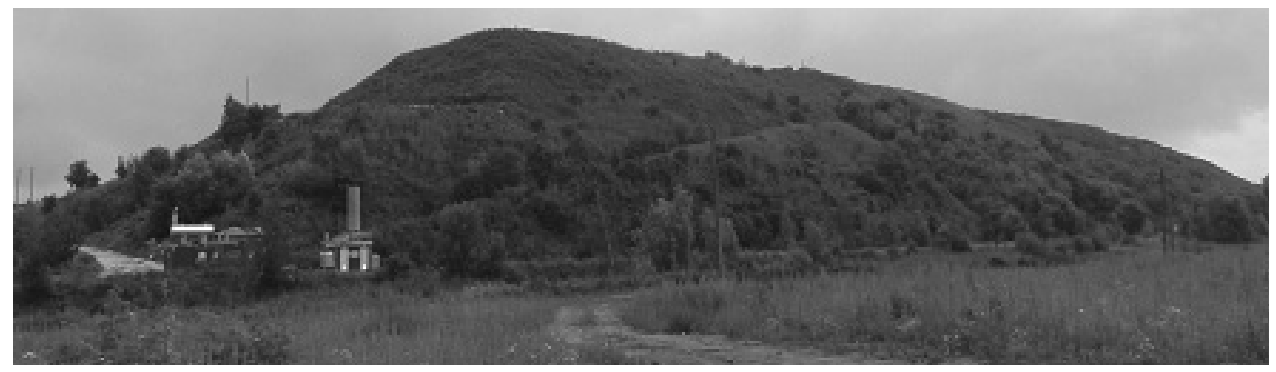

FIGURE 5. The effect of the hydroseeding method applied on Radiowo landfill

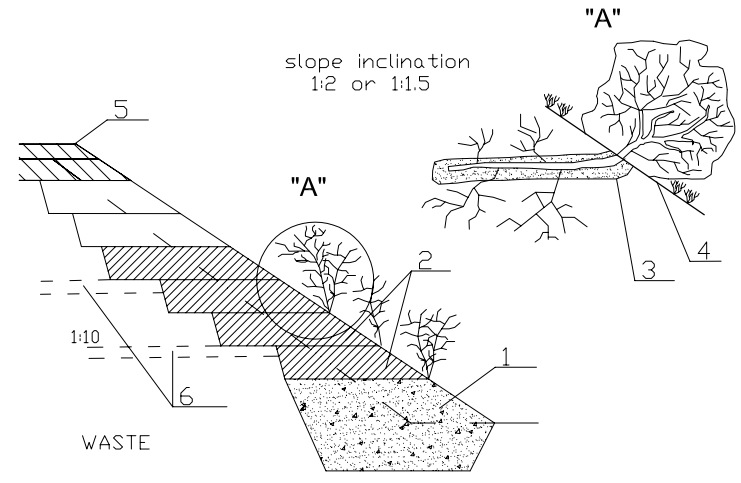

FIGURE 6. Conception of the biological rehabilitation of high inclination slope of old sanitary landfill: 1 - petrified ash, 2 - condensed ashes, 3 - bundles of the fascine laid in the layer of dewatered sewage sludge, 4 - surfaces greened by the hydroseeding, 5 - protective layers seeded by the mixtures of grasses, 6 - adjusted sanitary layers (sludge-ashes mixture) (Koda and Głażewski 2006) 
INFLUANCE OF THE VEGETATION COVER AND THE LANDFILL SLOPE STABILITY ASSESSMENT

All of the methods and techniques described above aim the slope stability improvement and are closely related to the vegetation cover influence. Thus it is worth to assess how plants itself can increase the factor of safety of the landfill slopes.

For the stability assessment it is recommended to use General Greenwood Method (Osiński 2010). Greenwood developed an equation (Greenwood 2006), based on the limit equilibrium method, where parameters of plants existing on the slope are considered. These parameters are: root reinforcement forces, wind forces, or the mass of vegetation, or related to these, changes in the pore water pressure. This method was basically developed to assess the stability of slope according to the soil reinforcement by anchors or geotextiles, or vegetation effects. The general approach of the slope stability computation involving vegetation cover is presented in Figure 7. It is presented how in a basic way the value of the factor of safety can be increased, and how important it is to remember that vegetation can greatly influence slope stability. Some of the results obtained by using GGM are presented below in the Table 3 .

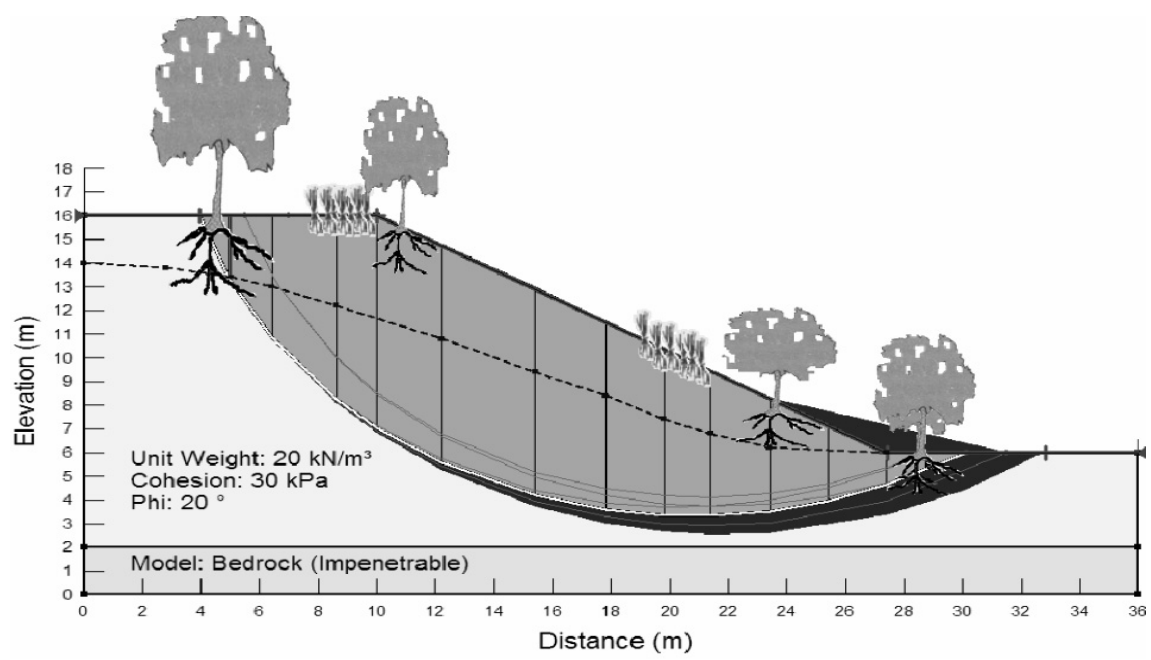

FIGURE 7. Effect of the vegetation cover on slopes (FOS calculated by using Slip4EX, the geometry of the failure surface computed by GeoStudio2007)

TABLE 3. Changes of Safety Factor for the landfill slope according to vegetation presence

\begin{tabular}{|l|l|l|l|l|l|l|}
\hline Slope parameters & \multicolumn{2}{l|l}{$\mathrm{H}=10 \mathrm{~m}, \beta=40^{\circ}$} & \multicolumn{2}{l|}{$\mathrm{H}=8 \mathrm{~m}, \beta=40^{\circ}$} & \multicolumn{2}{l|}{$\mathrm{H}=6 \mathrm{~m}, \beta=40^{\circ}$} \\
\hline Material parameters & \multicolumn{2}{|l|l}{$\begin{array}{l}\gamma=18 \mathrm{~kg} / \mathrm{m}^{3}, \\
\mathrm{c}=10 \mathrm{kPa}, \varphi=20^{\circ}\end{array}$} & $\begin{array}{l}\gamma=18 \mathrm{~kg} / \mathrm{m}^{3}, \\
\mathrm{c}=10 \mathrm{kPa}, \varphi=20^{\circ}\end{array}$ & \multicolumn{2}{l|}{$\begin{array}{l}\gamma=18 \mathrm{~kg} / \mathrm{m}^{3}, \\
\mathrm{c}=10 \mathrm{kPa}, \varphi=20^{\circ}\end{array}$} \\
\hline Presence of vegetation & No Veg & Veg & No Veg & Veg & No Veg & Veg \\
\hline FOS & 1.01 & 1.14 & 1.13 & 1.26 & 1.36 & 1.56 \\
\hline
\end{tabular}


The research was focused on distribution, weight and tensile root strength parameters of plants, rather than on selecting specific species of vegetation. The characteristics of root system for the analysed cases were collected from (Coppin and Richards 1990). It has also been presented that simple activity like vegetation establishment can increase the factor of safety by as much as $20 \%$.

\section{SLOPES REINFORCEMENT} PROPOSAL OF AN OLD SANITARY LANDFILL

Considering a reclamation process of any landfill, firstly the amount and range of works has to be estimated. There are two major cases to be specified before starting reclamation:

- if the closure procedure considers a properly constructed landfill (legacy and environmental requirements were fulfilled during construction),

- if the closure procedure considers a landfill which has not met any normative requirements (refers to old landfills constructed before establishing legacy standards).

The first case includes principal reclamation works such as: waste body engineering, degassing system installation, adjustment layer and capping system, and reclamation layer installation. Regarding the second case, more complex activity is required.

Old landfills, has to be additionally protected against further environmental degradation. Thus, the reclamation process has to meet requirements specified in the land management project, and significantly reduce the environmental impact on the surrounding area. Well improved landfill area is often recognized as a great background for forestry purpose, arable fields or becoming more common, used as a recreational facility.

However, the reclamation of embankment type landfill involve additional problem such as waste body slope engineering, which inclination rises to more than $1: 1$. The difficulty is that vegetation cannot be established properly before shaping works, laying sealing layer, then topsoil (20-50 cm thickness) or fermented and sieved municipal waste, or mineral soil layer with organic fertilizers spreading. The landfill construction process also requires separating waste layers with natural soil. However, lack of fresh soil access, often eliminate this requirement to be met. Instead, the fly-ash or its mixture with sewage sludge can be used. The property of such material is highly valuable for plant, and has great hydroscopic parameters. The conceptual plan of reclamation works with the use of all described in this paper techniques, was successfully applied on one of the old landfill located in the central part of Poland. The landfill was established in late 70's on totally unprepared ground for such purpose. In 90's landfill was extended, however during the construction the new area was equipped with a ground sealing system. The height of the landfill is $30 \mathrm{~m}$ above the ground level. The inclinations of slopes vary from $1: 1.5 \div 1: 2.5$, what causes difficulties in capping layers and vegetation establishment. Initially, the western part of the landfill was reinforced with fascine, however it does not present significant slope stability improvement. In 2007 the northern slope was reinforced by using geogrid fulfilled with the fertilized soil, 


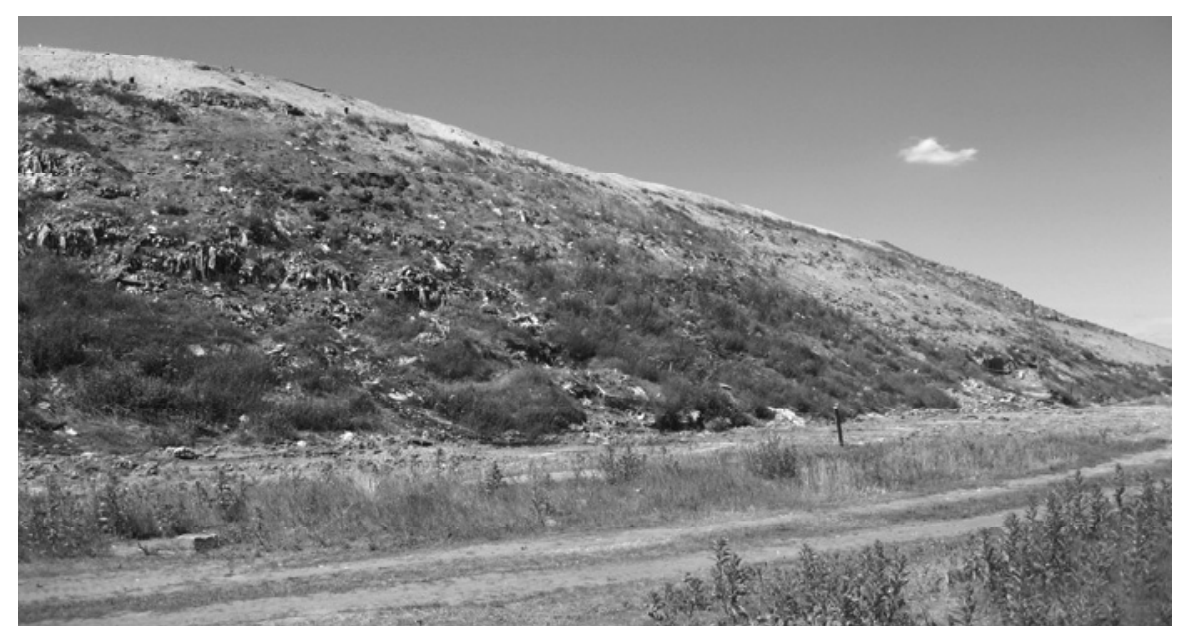

FIGURE 8. The eastern slope of the landfill before reinforcement works

and sprayed with grass seeds. However this combination does not show expected effects (Fig. 8). Reinforcement works on the eastern slope of the landfill has not been introduced at all. High inclination caused significant rillmarks, and local exposures of raw waste on the slope, especially in its central part, can be observed (Koda et al. 2008). The proposal of the reintroduction of the reclamation process, was to engineer selected slopes to the actual shape, and for the planned landfill extension. On the basis of the site investigation conducted, three erosion control and bio-engineering schemes were adopted. Before the reinforcement works the surface of slope was engineered to the even level.

The first scheme regards middle part of the eastern slope with the inclination of $1: 1.3 \div 1: 1.5$ :

1. Erosion control solutions - fascine fences: square segments $(1.2-1.5 \mathrm{~m})$.

2. Soil improvement within the poling square segments $-15 \mathrm{~cm}$ thickness of compacted layer (mixture of 1:1 volu- metric proportion - sand + sewage sludge and fly-ash).

3. Hydroseeding - (6 application) $\mathrm{min}$. $2-31 / \mathrm{m}^{2}$ sludge and ash + grass seeds $(200 \mathrm{~kg} / \mathrm{ha})+$ mulch $(100 \mathrm{~kg} / \mathrm{ha})+$ fertilizers NPK (200 kg/ha).

The northern part of eastern slope (inclination $1: 1.5 \div 1: 2$ ):

1 Erosion control solutions - bars: square segments $(1.5-2 \mathrm{~m})$.

2. Soil improvement within the bar square segments $-10 \mathrm{~cm}$ thickness of compacted layer (mixture of 1:1 volumetric proportion- sand + sewage sludge and fly-ash).

3. Hydroseeding - (4 application) $\mathrm{min}$. $2-31 / \mathrm{m}^{2}$ sludge and ash + grass seeds $(150 \mathrm{~kg} / \mathrm{ha})+\operatorname{mulch}(800 \mathrm{~kg} / \mathrm{ha})+$ fertilizers NPK $(150 \mathrm{~kg} / \mathrm{ha})$.

The southern part of the of the eastern slope, and the north slope (inclination $1: 2 \div 1: 2.5)$ :

1. Local bare soil fulfilling, and slope engineering.

2. Soil improvement within the poling square segments $-5 \mathrm{~cm}$ thickness of 


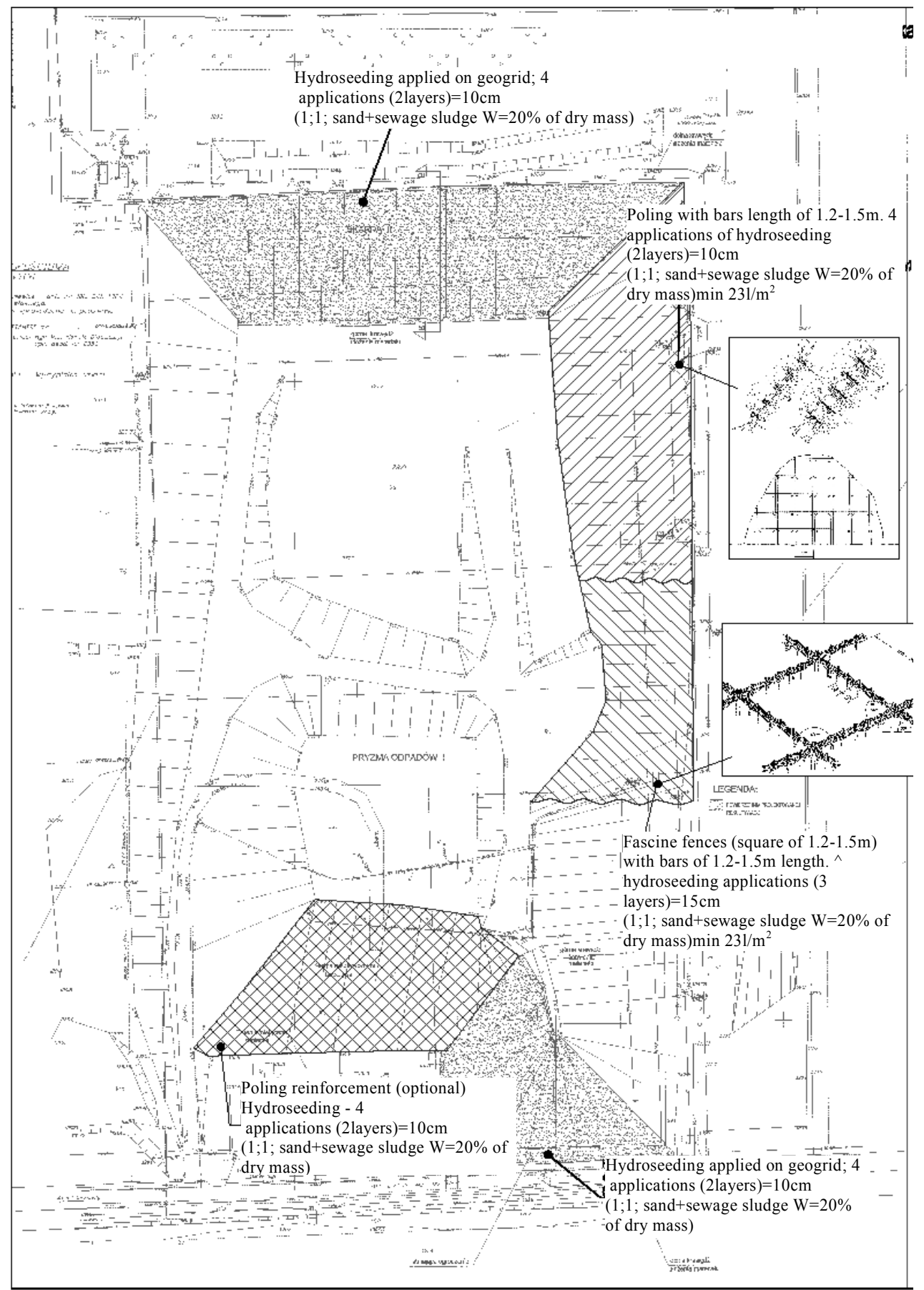

FIGURE 9. Conception of the reinforcement works on the old sanitary landfill slopes 
compacted layer (mixture of 1:1 volumetric proportion - sand + sewage sludge and fly-ash).

3. Hydroseeding - (2 application) min. 2-3 $\mathrm{l} / \mathrm{m}^{2}$ sludge and ash + grass seeds $(120 \mathrm{~kg} / \mathrm{ha})+$ mulch $(500 \mathrm{~kg} / \mathrm{ha})+$ fertilizers NPK $(120 \mathrm{~kg} / \mathrm{ha})$.

The visual scheme of the proposed solutions is presented in Figure 9.

As the fulfillment material for the gaps between fascine fences and bars, instead of topsoil, the mixture of the fermented sludge and fly-ash is used.

The compaction process of the improved soil, fulfilling fascine fences, was conducted by vertical stepping, which helps keeping the soil moister content, required for the proper development of vegetation. All the methods and techniques described above does not change the function of the structure, however it significantly decreases the environmental impact on the surrounding area, by eliminating erosion, dusting from the surface, increasing evapotranspiration, enhancing visual aspects, and make the area less unbearable for citizens.

\section{CONCLUSIONS}

Most of old landfills in Poland require immediate introduced reclamation procedures, as they cause significant damage to the surrounding environment. The partial solution for this issue is presented in the paper. There are available methods, which are relatively simple, efficient, and cost effective.

The use of fly ash and sewage sludge for the reclamation of the surface of landfill is an alternative. The benefits from the utilization of the fly-ash are: decreased leachate penetration through landfill, and its partial neutralization. It also solves the problem of the ash storage which, from the economical and environmental point of view, is very positive.

The hydroseeding method with the use of sewage sludge enables efficient landfill slope "green" cover (also enhancing vegetation development). No additional turf activities are required.

The reinforcement of slope does not require only heavy engineering methods, basic solution as a proper selection and implementation of plants is always worth consideration. It is definitely cost effective, environment friendly and reasonable technique accelerating landfill reclamation works.

\section{REFERENCES}

CEN/BT WG2003 2009: "Earthworks". Final report 6th February 2009.

COPPIN N.J., RICHARDS I.G. 1990: Use of vegetation in civil engineering. CIRIA - Butterworths, London.

GLAZEWSKI M., KALOTKA J. 1999: "Hydrodynamic seeding with the use of sewage sludge and fly-ash for slope protection". International Symposium on "Slope Stability Engineering", IS-Shikoku/Japan. A.A. Balkema, Rotterdam.

GREENWOOD J.R. 2006: SLIP4EX - A Program for Routine Slope Stability Analysis to Include the Effects of Vegetation, Reinforcement and Hydrological Changes. Geotechnical and Geological Engineering, 24 (3), 449-465.

KODA E. 1999: Remediation of the old embankment sanitary landfills. Proc. of the 2nd BGS Geoenvironmental Engineering Conference, Thomas Telford, London, 29-39.

KODA E., GLAZEWSKI M. 2006: Technical and biological reinforcement of rebuilt landfill slopes. Proc. of the 13th Danube-European Conference on Geotechnical Engineering. Ljubljana, Vol. 2, 275-280.

KODA E., PACHUTA K. 2004: Selection of plants in the initial stage of landfill reclamation process. Annals of Warsaw Agricultural University - SGGW, Land Reclamation, Vol. $35,41-50$. 
KODA E., GŁAŻEWSKI M., KOŁANKA T. 2008: Propozycja zabudowy biologicznej - zabezpieczenia przeciwerozyjnego skarp składowiska odpadów Franki k/Krośniewic, z wykorzystaniem hydroobsiewu. Geotechnika i Środowisko, Warszawa.

OSIŃSKI P. 2010: Guidelines for assessment of slope stability in small earth structures. MSc Thesis, Cranfield University.

Streszczenie: Zabezpieczenie przeciwerozyjne skarp z wykorzystaniem popiołów lotnych i osadów ściekowych. Jednym z najważniejszych elementów rekultywacji starych składowisk odpadów typu nadpoziomowego jest wzmocnienie i stabilizacja skarp dla zabezpieczenia przed utratą stateczności i niekorzystnymi procesami erozyjnymi. Prawidłowo przeprowadzone zabiegi powinny być podzielone na dwa etapy. W pierwszym etapie należy wykonać prace inżynierskie dla zapewnienia stateczności ogólnej skarpy (rekultywacja techniczna), natomiast w drugim etapie przeprowadza się zabiegi pratotechniczne dla wytworzenia zwartej szaty roślinnej na powierzchni skarp (rekultywacja biologiczna). Dla przyszłego zagospodarowania powierzchni składowiska podstawowe znaczenie ma zapewnienie odpowiedniego nachylenia skarp i uformowania warstwy przykrycia zgodnie $\mathrm{z}$ zasadami stosowanymi w robotach ziemnych (dobór gruntu i jego zagęszczenie). Do stabilizacji skarp składowisk mogą być stosowane mieszaniny z wykorzystaniem popiołów lotnych, gruntu i osadów ściekowych.

W artykule przedstawiono zasady i przykłady wykonywania konstrukcji ziemnych dla poprawy stateczności skarp oraz sposób stabilizacji powierzchni skarpy z wykorzystaniem popiołów lotnych. Popioły lotne i osady ściekowe stanowia materiał nawozowy bogaty w substancje mineralne i organiczne, wolno rozkładający się, przez co nie ulega wypłukiwaniu i jest łatwo przyswajalny przez rośliny. Wbudowywanie mieszanin na skarpach może być realizowane $\mathrm{z}$ wykorzystaniem hydroobsiewu lub innych technik stosowanych do zabudowy skarp. Metoda hydroobsiewu znalazła zastosowanie głównie w zadarnianiu skarp budowli ziemnych, np. nasypów drogowych, stawów osadowych i budowli hydrotechnicznych, ale może być również zastosowana do stabilizacji skarp składowisk i zwałowisk. Wykonana poprawnie i w odpowiednim czasie zabudowy skarp umożliwiają uzyskanie dobrej jakości zadarnienia. Właściwości popiołów lotnych poprawiają żyzność utworzonej na skarpie warstwy rekultywacyjnej i zwiększają jej pojemność wodna, stwarzającą korzystne warunki dla wprowadzenia i utrzymania roślinności w okresach suchych.

Słowa kluczowe: stateczność skarp, wzmocnienie, szata roślinna, materiały odpadowe, składowisko.

\section{MS. received October 15, 2011}

\section{Author's address:}

Eugeniusz Koda

Katedra Geoinżynierii

Szkoła Główna Gospodarstwa Wiejskiego

Nowoursynowska 159

02-776 Warszawa

Poland 